\title{
PERBEDAAAN PENURUNAN MASA BIOFILM STREPTOCOCCUS MUTANS ANTARA PEMBERIAN FRAKSI N-HEKSANA DAN ETIL ASETAT EKSTRAK ETANOL BAWANG PUTIH SIUNG TUNGGAL (Allium sativum L.)
}

Faizal Hasan*, Ratna Indriyanti*, Meirina Gartika*

Keywords:
Biofilm mass,
Streptococcus
mutans, n-hexane
fraction, ethyl
acetate fraction,
single-clove garlic

Keywords:

Biofilm mass,

Streptococcus

fraction, ethyl

acetate fraction,

single-clove garlic

\section{ABSTRACT}

Background: : Garlic (Allium sativum $L$ ) is one of the most important Allium species consumed worldwide and has been used for decades as a cure for various diseases. The aim of this research was to compare the efficacy of single-clove garlic's $n$-hexane and ethyl acetate fractions in inhibiting the growth of Streptococcus mutans biofilm Method: This was a true experimental research. The biofilm mass was determined by absorbance value at $590 \mathrm{~nm}$ wavelength with ELISA reader in a microplate using safranin. Data was analyzed using ANOVA followed by post hoc analysis with $\rho$ value $<0.05$.

Result: The result showed that average decrease of biofilm mass after 1-30 minutes of ethyl acetate fraction administration was $33.4 \pm 8.03 \mathrm{mg} / \mathrm{mL}$, $\mathrm{n}$-hexane $23.6 \pm 0.97 \mathrm{mg} / \mathrm{mL}$ and chlorhexidine $35.5 \pm 0.98 \mathrm{mg} / \mathrm{mL}$. The average decrease of biofilm mass after 30-60 minutes of ethyl acetate fraction administration was 11.94 $\pm 7.44 \mathrm{mg} / \mathrm{mL}$, n-hexane $43.87 \pm 41.6 \mathrm{mg} / \mathrm{mL}$ and chlorhexidine $16.35 \pm 4.6 \mathrm{mg} /$ $\mathrm{mL}$. Statistic analysis showed that there was a notable difference in the decrease of Streptococcus mutans biofilm mass ( $\rho$ value $=0.00$ ).

Conclusion: The conclusion of this research was that administrating either n-hexane or ethyl acetate fractions of a single-clove garlic has the ability to decrease S. mutans biofilm mass.

\section{PENDAHULUAN}

Seiring perkembangan zaman, masalah kesehatan khususnya kesehatan gigi dan mulut semakin meningkat. Hal tersebut disebabkan timbulnya penyakit gigi dan mulut yang dipengaruhi oleh interaksi berbagai faktor seperti pendidikan, status sosial, penghasilan, pola makan, pekerjaan, bahkan budaya manusia itu sendiri. Karies gigi dan penyakit periodontal merupakan dua penyakit gigi dan mulut yang paling sering ditemukan di klinik gigi. ${ }^{1,2}$

Berdasarkan Survei Kesehatan Rumah Tangga, prevalensi karies di Indonesia mencapai $90,1 \%$ dan tergolong lebih tinggi dibandingkan dengan negara berkembang lainnya. Karies merupakan salah satu bukti kondisi gigi dan mulut masyarakat Indonesia yang tidak terawat. Menurut data Departemen Kesehatan
(Riskesdas 2007) menunjukkan bahwa nilai DMF-T adalah 4,85 . Sebanyak $72 \%$ penduduk Indonesia mempunyai pengalaman karies dan $46,5 \%$ diantaranya karies aktif yang belum dirawat. Hal ini akibat perilaku masyarakat Indonesia yang buruk dalam menjaga kesehatan gigi dan mulut. Data menunjukkan bahwa $91,1 \%$ penduduk Indonesia usia 10 tahun ke atas melakukan sikat gigi satu kali sehari, dan hanya $7,3 \%$ yang telah menggosok gigi dua kali sehari pada waktu yang benar, yaitu pagi hari setelah makan dan malam sebelum tidur. $^{3-5}$ Tujuan menyikat gigi adalah untuk menghilangkan plak gigi penyebab karies. ${ }^{5}$

Plak gigi merupakan masa atau lapisan tipis berwarna putih yang terbentuk akibat aktivitas metabolik bakteri gigi sehingga dapat menyebabkan karies. ${ }^{6}$ Streptococcus mutans adalah bakteri kokus gram-positif, non-motil,

\footnotetext{
* Departemen IImu Kedokteran Gigi Anak Fakultas Kedokteran Gigi Universitas Padjajaran Korespondensi: meirina.gartika@fkg.unpad.ac.id
} 
tidak membentuk spora, mikroorganisme anaerobik fakultatif yang biasa ditemukan pada rongga mulut manusia, dan merupakan kontributor yang signifikan dalam kerusakan gigi. S. mutans dapat memetabolisme karbohidrat, memproduksi asam, dan membentuk biofilm sehingga menyebabkan terjadinya karies pada gigi. ${ }^{7,8}$ Plak gigi merupakan salah satu bentuk biofilm. $^{7}$

Banyak cara yang telah digunakan dalam menghilangkan biofilm, diantaranya yaitu dengan penyikatan gigi dan cara kimiawi menggunakan bahan antibakteri. Bahan anti bakteri mampu membunuh atau mengurangi jumlah bakteri pada biofilm dengan cara merusak dinding sel. Berbagai bahan antibakteri tersedia dalam bentuk obat kumur, pasta gigi maupun varnish. ${ }^{9-11}$

Beberapa tahun terakhir perhatian pemerintah Indonesia terhadap pemanfaatan obat herbal di bidang kesehatan terus meningkat. Banyak penelitian yang ditujukan untuk mengembangkan bahan herbal sebagai sumber obat yang memiliki efek antimikroba. Bahan herbal dapat mengurangi efek samping dan lebih ekonomis. ${ }^{12}$

Salah satu tanaman yang mempunyai khasiat obat adalah bawang putih (Allium sativum L.), termasuk dalam familia Liliaceae. Bawang putih merupakan salah satu spesies Allium paling penting yang dikonsumsi di seluruh dunia dan telah digunakan selama puluhan tahun sebagai obat untuk berbagai penyakit. Secara tradisional, bawang putih telah digunakan sebagai antiseptik, ekspektoran, antihipertensi, stimulan, karminatif, afrodisiak, diaforetik, antelmintik, diuretik, antiskorbut, dan untuk pengobatan infeksi virus. ${ }^{13}$

Maryati membandingkan daya hambat dan daya bunuh ekstrak bawang putih terhadap $S$. mutans dalam bentuk planktonik dan biofilm.
Ekstrak etanol bawang putih mempunyai daya hambat terhadap S. mutans ATCC 25175 dalam bentuk planktonik dan biofilm. ${ }^{14}$

\section{METODE PENELITIAN}

Jenis penelitian ini adalah eksperimenal murni, dengan persetujuan etik No.639/UN6.C.10/PN/2017 dari Komisi Etik Penelitian Kesehatan Fakultas Kedokteran Universitas Padjadjaran. Penelitian dilakukan di Laboratorium Aplikasi Kimia dan Pelayanan Universitas Padjadjaran. Bahan uji adalah fraksi n-heksana dan etil asetat bawang putih, akuades sebagai kontrol negatif dan klorheksidin sebagai kontrol positif.

\section{Penentuan zona hambat menggunakan metode disk diffusion}

Cakram kertas yang telah ditetesi senyawa uji diletakkan pada permukaan medium agar Mueller-Hinton. Zona hambat dilihat dari zona bening yang terjadi di sekeliling cakram. Pengukuran menggunakan jangka sorong setelah 48 jam masa inkubasi pada suhu $37^{\circ} \mathrm{C}$. Prosedur ini dilakukan dengan replikasi sebanyak 2 kali.

\section{Penentuan nilai KHM dan KBM}

Uji kadar hambat minimal (KHM) dan kadar bunuh minimal (KBM) dilakukan dengan metode mikrodilusi. S. mutans dimasukkan ke dalam media cair Mueller-Hinton dengan standar Mac Farland 0,5. Nilai KHM ditentukan sebagai konsentrasi paling rendah dari senyawa uji yang dapat menghambat pertumbuhan bakteri. Alat yang digunakan adalah Elisa reader. Nilai KBM adalah konsentrasi minimal dari bahan uji sehingga bakteri tidak dapat tumbuh. Didapat dari nilai KHM, kemudian dilakukan penanaman pada media padat Mueller-Hinton. 
Pemeriksaan masa biofilm menggunakan safranin

Pembuatan biofilm dilakukan dengan cara menambahkan saliva terhadap media cair Mueller Hinton yang berisi bakteri S. mutans yang telah diencerkan dengan konsentrasi 0,5 Mac Farland dalam microtube dengan perbandingan saliva dan kultur bakteri yaitu $60 \mu \mathrm{l}$ : $240 \mu \mathrm{l}$. Selanjutnya diinkubasi selama 48 jam pada temperatur $37^{\circ} \mathrm{C}$ dalam kondisi anaerob (10\%, CO2). Setelah terbentuk biofilm, pada masing-masing microtube ditambahkan 1 tetes akuades sebagai kontrol negatif, fraksi n-heksana, fraksi etil asetat ekstrak bawang putih tunggal dan klorheksidin sebagai kontrol positif. Masing-masing pemberian bahan uji pada biofilm memiliki interval waktu 1, 30 dan 60 menit. Selanjutnya ditambahkan pewarnaan safranin dan diukur nilai absorbansi pada panjang gelombang $590 \mathrm{~nm}$ dengan alat ELISA reader dalam microplate.

\section{Analisis statistik}

Analisis data menggunakan uji ANOVA (Analysis of Variances) dua arah, kemudian dilanjutkan dengan uji Post Hoc. Seluruh analisis dilakukan menggunakan program statistik
Excel Megastat.

\section{HASIL PENELITIAN}

\section{Zona hambat fraksi n-heksana bawang pu- tih siung tunggal}

Tabel 1 menunjukkan zona hambat fraksi n-heksana bawang putih pada konsentrasi 5.000 ppm, 10.000 ppm dan 20.000 ppm terhadap pertumbuhan $\mathrm{S}$. mutans.

\section{Zona hambat fraksi etil asetat bawang putih suing tunggal}

Tabel 2 menunjukkan zona hambat aktif fraksi etil asetat pada semua konsentrasi mulai dari konsentrasi 5.000 ppm, 10.000 ppm dan 20.000 ppm.

\section{Konsentrasi hambat minimum (KHM)}

Nilai KHM fraksi etil asetat sebesar 312,5 ppm dapat dilihat pada Tabel 3 dan hasil pengukuran KHM fraksi n-heksana dapat dilihat pada Tabel 4.

\section{Konsentrasi bunuh minimum (KBM)}

Setelah nilai KHM diperoleh, maka nilai tersebut menjadi acuan untuk menentukan nilai KBM. Nilai KBM untuk fraksi etil asetat adalah 1250 ppm dan fraksi n-heksana adalah 2500 ppm.

Tabel 1 Nilai Zona Hambat Fraksi N-Heksana terhadap Pertumbuhan S. mutans

\begin{tabular}{|c|c|c|c|c|c|}
\hline No. & Sampel \& Konsentrasi (ppm) & pengl & $\begin{array}{l}\text { ter } \\
\text { batan }\end{array}$ & $\begin{array}{l}\text { Rata-rata } \\
(\mathrm{mm})\end{array}$ & Keterangan \\
\hline 1 & $\begin{array}{l}\text { Fraksi } n \text {-heksana bawang putih } \\
(20.000)\end{array}$ & 10.40 & 9.80 & 10.10 & Aktif \\
\hline 2 & $\begin{array}{l}\text { Fraksi } n \text {-heksana bawang putih } \\
(10.000)\end{array}$ & 9.10 & 8.40 & 8.75 & Aktif \\
\hline 3 & $\begin{array}{l}\text { Fraksi } n \text {-heksana bawang putih } \\
(5.000)\end{array}$ & 7.90 & 7.60 & 7.75 & Aktif \\
\hline 4 & Kontrol negatif: pelarut etanol & - & - & - & Tidak Aktif \\
\hline 5 & Kontrol Positif :Klorheksidin(2.000) & 14.20 & 14.30 & 14.25 & Susceptible \\
\hline
\end{tabular}


Tabel 2 Nilai Zona Hambat Fraksi Etil Asetat terhadap Pertumbuhan S. mutans

\begin{tabular}{|c|c|c|c|c|c|}
\hline No. & Sampel \& Konsentrasi (ppm) & $\begin{array}{r}\text { Dia } \\
\text { pengh }\end{array}$ & $\begin{array}{l}\text { ter } \\
\text { batan }\end{array}$ & $\begin{array}{l}\text { Rata-rata } \\
(\mathrm{mm})\end{array}$ & Keterangan \\
\hline 1 & $\begin{array}{l}\text { Fraksi etil asetat bawang putih } \\
(20.000)\end{array}$ & 12.40 & 13.20 & 12.80 & Aktif \\
\hline 2 & $\begin{array}{l}\text { Fraksi etil asetat bawang putih } \\
(10.000)\end{array}$ & 10.20 & 9.10 & 9.65 & Aktif \\
\hline 3 & $\begin{array}{l}\text { Fraksi etil asetat bawang putih } \\
(5.000)\end{array}$ & 8.60 & 8.20 & 8.40 & Aktif \\
\hline 4 & $\begin{array}{l}\text { Kontrol pelarut metanol : Air }(3: 1) \\
\text { (negatif) }\end{array}$ & - & - & - & Tidak Aktif \\
\hline 5 & Kontrol Positif : $\mathrm{K}(2.000)$ & 20.10 & 17.00 & 18.55 & Susceptible \\
\hline
\end{tabular}

Tabel 3 Hasil Penaukuran KHM Fraksi Etil Asetat

\begin{tabular}{|c|c|c|c|c|c|c|c|c|c|c|c|c|}
\hline $\begin{array}{c}\text { Rata- } \\
\text { rata }\end{array}$ & 10000 & 5000 & 2500 & 1250 & 625 & 312,5 & 156,25 & 78,12 & 39,06 & 19,53 & 9,76 & 4,88 \\
\hline $\mathbf{M}+\mathbf{P}$ & 0,055 & 0,050 & 0,048 & 0,047 & 0,047 & 0,045 & 0,045 & 0,046 & 0,047 & 0,047 & 0,046 & 0,047 \\
\hline $\mathrm{M}+\mathrm{S}$ & 1,175 & 1,005 & 0,574 & 0,323 & 0,156 & 0,100 & 0,073 & 0,062 & 0,056 & 0,055 & 0,055 & 0,053 \\
\hline $\mathrm{M}+\mathrm{P}+\mathrm{B}$ & 0,061 & 0.062 & 0,119 & 0.552 & 0,391 & 0,326 & 0,625 & 0,846 & 0,847 & 0,728 & 0,776 & 0,689 \\
\hline $\mathrm{M}+\mathrm{S}+\mathrm{B}$ & 1,337 & 1,308 & 1,172 & 0,619 & 0,410 & 0,334 & 0,729 & 0,850 & 0,806 & 0,749 & 0,799 & 0,645 \\
\hline
\end{tabular}

Tabel 4 Hasil Pengukuran KHM Fraksi N-Heksana

\begin{tabular}{|c|c|c|c|c|c|c|c|c|c|c|c|c|c|}
\hline & $\begin{array}{l}\text { Rata- } \\
\text { rata }\end{array}$ & 10000 & 5000 & 2500 & 1250 & 625 & 312,5 & 156,25 & 78,12 & 39,06 & 19,53 & 9,76 & 4,88 \\
\hline $\mathbf{A}$ & $\mathrm{M}+\mathrm{P}$ & 0,0655 & 0,0455 & 0,0460 & 0,0450 & 0,0455 & 0,0470 & 0,0515 & 0,0470 & 0,0480 & 0,0510 & 0,0470 & 0,0565 \\
\hline B & $\mathbf{M}+\mathrm{S}$ & 0,7460 & 0,1670 & 0,0615 & 0,0480 & 0,0495 & 0,0445 & 0,0455 & 0,0480 & 0,0465 & 0,0475 & 0,0510 & 0,0485 \\
\hline $\mathrm{C}$ & $\mathrm{M}+\mathrm{P}+\mathrm{B}$ & 0,525 & 0,1380 & 0,1160 & 0,1110 & 0,1435 & 0,1050 & 0,0975 & 0,1000 & 0,1460 & 0,1530 & 0,1615 & 0,1690 \\
\hline & $\mathrm{M}+\mathrm{S}+\mathrm{B}$ & 0,5550 & 0,1670 & 0,1250 & 0,1335 & 0,1400 & 0,0935 & 0,0895 & 0,0980 & 0,1380 & 0,1280 & 0,1130 & 0,2055 \\
\hline
\end{tabular}

Tabel 5 Perbedaan Penurunan Masa Biofilm S. mutans Setelah Induksi Fraksi Etil Asetat Bawang Putih Dan Klorheksidin

\begin{tabular}{ccccc}
\hline $\begin{array}{c}\text { Waktu } \\
\text { (menit) }\end{array}$ & $\begin{array}{c}\text { Tanpa } \\
\text { Perlakuan }\end{array}$ & $\begin{array}{c}\text { Rata-rata } \\
\text { Penurunan dan } \\
\text { SD Etil Asetat }\end{array}$ & $\begin{array}{c}\text { Rata-rata } \\
\text { Penurunan } \\
\text { dan SD } \\
\text { Klorheksidin }\end{array}$ & $\rho$-value \\
\hline ''-30' & 1,521 & $33,4 \pm 8,03$ & $35,5 \pm 0,98$ & 0,676 \\
30 '-60' & 1,680 & $11,94 \pm 7,44$ & $16,35 \pm 4,6$ & 0,432 \\
\hline Keterangan : nilai p dihitung berdasarkan uji ANOVA & \\
SD = standar deviasi
\end{tabular}


Tabel 6 Perbedaan Penurunan Masa Biofilm S. mutans Setelah Induksi Fraksi n-Heksana Bawang Putih Dan Klorheksidin

\begin{tabular}{ccccc}
\hline $\begin{array}{c}\text { Waktu } \\
\text { (menit) }\end{array}$ & $\begin{array}{c}\text { Tanpa } \\
\text { Perlakuan }\end{array}$ & $\begin{array}{c}\text { Rata-rata } \\
\text { Penurunan } \\
\text { dan SD } n \text { - } \\
\text { heksana }\end{array}$ & $\begin{array}{c}\text { Rata-rata } \\
\text { Penurunan } \\
\text { dan SD } \\
\text { Klorheksidn }\end{array}$ & $\rho$-value \\
\hline $1^{\prime}-30$ ' & 1,521 & $23,6 \pm 0,97$ & $35,5 \pm 0,98$ & $0,0001^{*}$ \\
$30^{\prime}-60$ ' & 1,680 & $43,87 \pm 41,6$ & $16,35 \pm 4,6$ & 0,3184 \\
\hline
\end{tabular}

Keterangan : nilai $\mathrm{p}$ dihitung berdasarkan uji ANOVA

$\mathrm{SD}=$ standar deviasi

Tabel 7 Perbedaan Penurunan Masa Biofilm Antara Induksi Fraksi N-Heksana dan Etil Asetat

\begin{tabular}{ccccc}
\hline $\begin{array}{c}\text { Waktu } \\
\text { (menit) }\end{array}$ & $\begin{array}{c}\text { Tanpa } \\
\text { Perlakuan }\end{array}$ & $\begin{array}{c}\text { Rata-rata } \\
\text { Penurunan } \\
\text { dan SD } n- \\
\text { heksana }\end{array}$ & $\begin{array}{c}\text { Rata-rata } \\
\text { Penurunan } \\
\text { dan SD Etil } \\
\text { Asetat }\end{array}$ & $\rho$-value \\
\hline ''-30' & 1,521 & $23,6 \pm 0,97$ & $33,4 \pm 8,03$ & 0,1030 \\
30 '-60' & 1,680 & $43,87 \pm 41,6$ & $11,94 \pm 7,44$ & 0,2609 \\
\hline \multicolumn{4}{c}{ Keterangan : nilai p dihitung berdasarkan uji ANOVA } \\
SD = standar deviasi
\end{tabular}

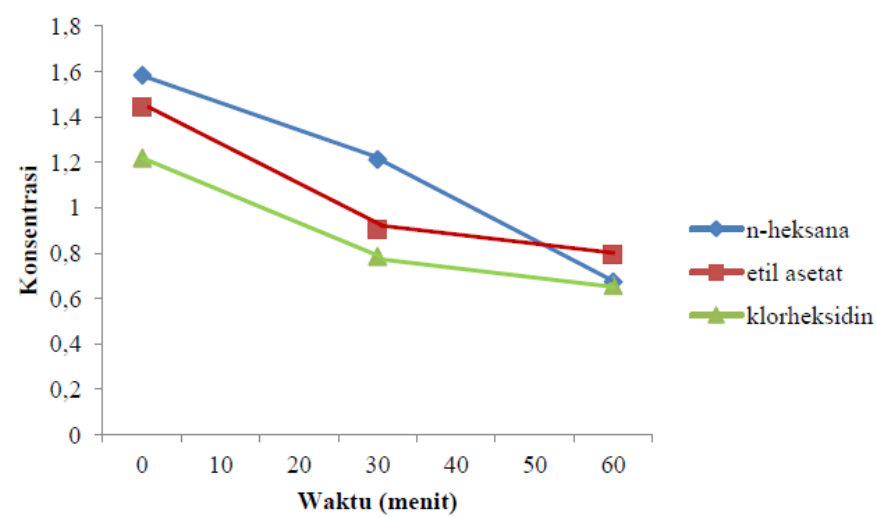

Gambar 1 Grafik Rata-rata Penurunan Masa Biofilm S. mutans pada pemberian fraksi etil asetat, n-heksan bawang putih dan klorheksidin berdasarkan lama pemberian

\section{Pemeriksaan masa biofilm menggunakan} Safranin

Tabel 5 menunjukkan perbedaan masa biofilm S. mutans setelah induksi ekstrak bawang putih siung tunggal fraksi etil asetat dan klorheksidin.

Tabel 6 menunjukkan penurunan masa biofilm S. mutans setelah induksi ekstrak bawang putih siung tunggal fraksi $n-\neg$ heksana dan klorheksidin.

Tabel 7 menunjukkan perbedaan pengaruh induksi fraksi n-heksana dengan etil asetat ekstrak bawang putih siung tunggal terhadap masa biofilm S. mutans.
Gambar 1 menunjukkan grafik perbandingan penurunan masa biofilm S. mutans setelah induksi fraksi n-heksana, etil asetat, dan klorheksidin.

\section{DISKUSI}

Tabel 1 menunjukkan bahwa fraksi n-heksana bawang putih mempunyai daya antibakteri terhadap $S$. mutans pada konsentrasi 5000 ppm dengan zona hambat $7,75 \mathrm{~mm}$. Hal ini tidak sesuai dengan penelitian Rayani dan Lestari yang menunjukkan bahwa fraksi n-heksana tidak memberikan zona hambat terhadap 
S. mutans. ${ }^{15,16}$

Tabel 2 menunjukkan bahwa fraksi etil asetat bawang putih mempunyai daya antibakteri terhadap S. mutans pada konsentrasi 5000 ppm dengan zona hambat $8,40 \mathrm{~mm}$. Penelitian Rayani, menunjukkan bahwa uji aktivitas antibakteri fraksi etil asetat daun ekor naga $(R$. pinnata) terhadap S. mutans pada konsentrasi $300 \mathrm{mg} / \mathrm{ml}$ dapat menghambat pertumbuhan bakteri dengan diameter inhibisi sebesar 16,3 $\mathrm{mm} .{ }^{15}$ Penelitian Lestari, menunjukkan fraksi etil asetat ekstrak etanol daun jambu mete (Anacardium occidentale L.) terhadap S. mutans pada konsentrasi $5 \mathrm{mg} / \mathrm{ml}$ dapat menghambat pertumbuhan bakteri dengan diameter inhibisi sebesar $13,33 \mathrm{~mm} .{ }^{16}$ Penelitian ini menunjukkan bahwa terdapat perbedaan zona hambat pada masing-masing bahan uji. Perbedaan ini dapat disebabkan oleh konsentrasi fraksi ekstrak bawang putih. Konsentrasi fraksi ekstrak bawang putih mempengaruhi kecepatan difusi, makin besar konsentrasi fraksi bawang putih maka difusi makin cepat, akibatnya makin besar daya antibakteri, maka makin luas diameter zona inhibisi yang terbentuk. ${ }^{16}$

Tabel 3 menunjukkan KHM ekstrak bawang putih siung tunggal fraksi etil asetat terhadap pertumbuhan S. mutans pada konsentrasi $312,5 \mathrm{ppm}(0,3125 \mathrm{mg} / \mathrm{mL})$. Pada penelitian Octareza, ekstrak temulawak memiliki nilai KHM fraksi etil asetat pada konsentrasi 0,25 $\mathrm{mg} / \mathrm{mL}$. Perbedaan nilai KHM disebabkan karena jenis tumbuhan yang digunakan. Ekstrak temulawak memiliki kandungan senyawa fenolik yang berperan dalam menghambat pertumbuhan bakteri S. mutans. Kandungan total fenol ekstrak metanol daun temulawak sebesar $1.15 \% \mathrm{~b} / \mathrm{b}$, yang dapat menghambat dan membunuh koloni S. mutans pada konsentrasi minimum sebesar 15,63 x 10-3 mg/mL. ${ }^{17}$

Nilai KHM ekstrak bawang putih siung tung- gal fraksi n-heksana terhadap pertumbuhan $S$. mutans (Tabel 4) pada konsentrasi 1250 ppm $(1,25 \mathrm{mg} / \mathrm{mL})$. Pada penelitian Novita18, ekstrak daun sirih (Piper betle $L$ ) memiliki nilai KHM fraksi n-heksana pada konsentrasi 1,25 $\mathrm{mg} / \mathrm{mL}$. Bawang putih siung tunggal pada penelitian ini memiliki daya hambat terhadap $S$. mutans yang sama efektif dengan daun sirih (Piper betle L). Daun sirih mengandung minyak atsiri dimana komponen utamanya terdiri atas fenol sebagai antibakteri yang dapat menyebabkan kerusakan pada sel bakteri, denaturasi protein, menginaktifkan enzim dan menyebabkan kebocoran sel. ${ }^{19,20}$

Nilai KBM ekstrak bawang putih siung tunggal fraksi etil asetat terhadap S. mutans pada konsentrasi 1250 ppm (1,25 mg/mL). Pada penelitian Octareza, ekstrak temulawak memiliki nilai KBM fraksi etil asetat dengan konsentrasi $0,5 \mathrm{mg} / \mathrm{mL}$. Perbedaan nilai KBM disebabkan karena jenis tumbuhan yang digunakan. Fraksi etil asetat mempunyai aktivitas kuat yang dapat menghambat koloni S. mutans karena kandungan kimia yang bersifat polar sehingga senyawa aktif antibakteri akan mudah larut. ${ }^{17}$

KBM ekstrak bawang putih siung tunggal fraksi n-heksana terhadap S. mutans pada konsentrasi $2500 \mathrm{ppm}$ adalah 2,5 mg/mL. Pada penelitian Octareza, ekstrak temulawak memiliki nilai KBM fraksi $n$-heksana dengan konsentrasi $1 \mathrm{mg} / \mathrm{mL}$. Perbedaan nilai KBM disebabkan karena jenis tumbuhan yang digunakan. Aktivitas antibakteri dari ekstrak tanaman temulawak sering dihubungkan dengan adanya kandungan senyawa fenolik dan flavonoid yang bertanggungjawab dalam menghambat dan membunuh pertumbuhan bakteri S. mutans. ${ }^{17}$

Tabel 5 menunjukkan rata-rata penurunan masa biofilm S. mutans pada pemberian klorheksidin mempunyai nilai lebih besar diband- 
ingkan dengan fraksi etil asetat bawang putih. Klorheksidin memiliki kemampuan penetrasi yang tinggi ke dalam biofilm gigi sehingga memungkinkan membunuh bakteri patogen, serta berikatan erat pada struktur gigi, plak gigi, dan jaringan mulut. Selain itu, klorheksidin dapat menghambat kerja glukosiltransferase yang penting untuk pembentukan glukan dan metabolisme fosfotransferase fosfofenolpiruvat yang terlibat dalam transportasi dan fosforilasi glukosa di seluruh membran. ${ }^{21,22}$ Contoh bahan alam lain yang dilaporkan memiliki potensi dalam menghambat pembentukan biofilm adalah minyak atsiri daun jahe merah, dengan nilai sebesar $0,218 \mathrm{mg} / \mathrm{mL}$. Nilai tersebut menunjukkan aktivitas yang cukup baik untuk menghambat pembentukan biofilm. ${ }^{23}$

Tabel 6 menunjukkan bahwa rata-rata penurunan masa biofilm pada menit 1-30 pemberian klorheksidin lebih besar dibandingkan dengan fraksi n-heksana bawang putih, terjadi sebaliknya pada pemberian menit 3060. Kandungan bahan aktif pada sampel yang memiliki aktivitas antibakteri, harus mampu menghancurkan dan menghilangkan lapisan eksopolisakarida pembentuk biofilm. ${ }^{24}$ Aktivitas antibakteri ekstrak bawang putih yang kurang pada penelitian ini karena proses perendaman (maserasi) sehingga menyebabkan konsentrasi senyawa aktif tersebut semakin rendah. Senyawa aktif ini berperan dalam menghambat pembentukan glukan oleh glukosiltransferase S. mutans. Menurut penelitian DePaola dan Spolarich, senyawa aktif yang terdapat dalam $1 \mathrm{~mL}$ obat kumur komersial mengandung beberapa zat aktif, diantaranya $0.092 \%$ eukaliptol, $0.042 \%$ mentol, $0.064 \%$ timol, dan $0.060 \%$ metilasetat. ${ }^{25}$ Senyawa aktif ini yang dapat menghambat pembentukan biofilm pada konsentrasi terkecil.

Pada Tabel 7, rata-rata penurunan masa biofilm pada pemberian fraksi etil asetat bawang putih menit 1-30 lebih besar dibandingkan dengan n-heksana, dan terjadi sebaliknya pada menit 30-60. Pada penelitian Sari dkk, aktivitas antibakteri fraksi n-heksana dengan nilai $0,91 \pm 0,01 \mathrm{mg} / \mathrm{mL}$ terhadap biofilm Escherichia coli tidak sebaik fraksi etil asetat dengan nilai $0,21 \pm 0,17 \mathrm{mg} / \mathrm{mL}$ Fraksi etil asetat dari sampel uji menunjukkan aktivitas antibakteri dalam menghambat pembentukan biofilm paling besar terhadap E. coli dan berkorelasi positif dengan peningkatan konsentrasi sampel uji. Fraksi etil asetat dari kapulaga dan senggugu mengandung senyawa fenolik dan flavonoid selain senyawa terpenoid. ${ }^{26} \mathrm{Ha}$ sil penelitian Octareza menunjukkan bahwa fraksi etil asetat pada daun tanaman Zingiberaceae memiliki senyawa aktif seperti alkaloid, flavonoid, triterpenoid, steroid dan tanin yang lebih dominan dibandingkan dengan fraksi n-heksana. ${ }^{17}$ Uji secara kualitatif terhadap flavonoid ekstrak daun kapulaga dan temulawak putih, menunjukkan paling tinggi intensitasnya dibandingkan jenis daun lain. Kadar flavonoid tersebut menyebabkan ekstrak etil asetat memiliki aktivitas antibakteri yang tinggi dalam menghambat pembentukan biofilm dari semua daun. ${ }^{26}$

\section{KESIMPULAN}

Berdasarkan hasil penelitian ini dapat disimpulkan bahwa pemberian fraksi n-heksana dan etil asetat bawang putih siung tunggal dapat menurunkan masa biofilm S. mutans. Disarankan untuk dilakukan penelitian lanjutan dengan menggunakan bahan senyawa aktif bawang putih seperti allicin serta dilakukan hitung jumlah koloninya, sehingga diketahui penyebab penurunan masa biofilm. 


\section{DAFTAR PUSTAKA}

1. Sabir A. Aktivitas Antibakteri flavonoid propolis Trigona sp terhadap bakteri Streptococcus mutans (in vitro). Dent J. 2005;38(3):135-41.

2. Ngantung RA, Pangemanan DHC, Gunawan PN. Pengaruh tingkat sosial ekonomi orang tua terhadap karies anak di TK Hang Tuah Bitung. Jurnal e-GiGi(eG). 2015;3(2).

3. Noviani N. Faktor-faktor yang berhubungan dengan status karies gigi (Dmft) santri pesantren $\mathrm{Al}$ Ashriyyah Nurul Iman Parung Bogor Tahun 2010. Tesis. 2010:3-4.

4. Winda SU, Gunawan P, Wicaksono DA. Gambaran karies rampan pada siswa pendidikan anak usia dini di Desa Pineleng II Indah. Jurnal e-GiGi(eG). 2015;3:1.

5. Widayati N. Faktor yang berhubungan dengan karies gigi pada anak usia 4-6 tahun. Jurnal Berkala Epidemiologi.2(2):196-205.

6. Fejerskov O, Kidd E. Dental caries; the diesease and its clinical management. Blackwell Publishing Ltd, UK. 2008:166-73.

7. Sherbiny GME. Control of growth Streptococcus mutans isolated from saliva and dental caries. Curr Microbiol App Sci 2014;3(10):1-10.

8. David BU, Linda OO, Charles OE. Isolation, characterization and antibiotic susceptibility studies of clinical isolates of Streptocococcus mutans obtained from patients visiting major dental clinics in Nsukka, Nigeria. AJPSP. 2011;2(1):1-15.

9. Cameron AC, Widmer RP. Dental caries and restorative paediatric dentistry. In Cameron, Editor. Handbook of Pediatric Dentistry. Mosby. 2003:44-5.

10. Lamont RJ, Burne RA, Lsntz MS, Blance DJL. Oral microbiology and immunology. ASM Press. Washington DC. 2006:233-52.

11. Pinkham J, Fields HW. Periodontal problem in children and adolescents in Pediatric Dentistry by Pinkham. Saunders Co. 2005.

12. Hendarwati M. Efek Antibakteri ekstrak daun jeruk purut (Citrus hystrix) terhadap bakteri Streptococcus mutans (In Vitro). Skripsi. 2014:1-3.

13. Lawal B, Shittu OK, Oibiokpa FI, Mohammed $\mathrm{H}$, Umar SI. Antimicrobial evaluation, acute and sub-acute toxicity studies of Allium sativum. Acute Disease. 2016;5(4):296-301.

14. Maryati L. Perbandingan daya hambat ekstrak etanol bawang putih (Allium sativum) terhadap Streptococcus mutans ATCC 25175 dalam bentuk planktonik dengan bentuk biofilm secara invitro. Tesis. Universitas Padjadjaran. 2015.

15. Rayani I. Uji aktivitas antibakteri ekstrak etanol dan beberapa fraksi daun ekor naga (Rhaphidopora Pinnata) terhadap bakteri Streptococcus mutans dan Pseudomonas aeruginosa. Universitas Sumatera Utara Skripsi. 2012:6.

16. Lestari M. Uji aktivitas antibakteri ekstrak etanol, fraksi n-heksan, fraksi kloroform dan fraksi etila- setat daun jambu mete (Anacardium occidentale L.). Universitas Sumatera Utara. Skripsi. 2016:6.

17. Octareza R. Penapisan Ekstrak daun Zingiberaceae sebagai antibakteri Streptococcus mutans dan pendegradasi biofilm pada gigi. Institut Pertanian Bogor Skripsi. 2016.

18. Novita W. Uji Aktivitas antibakteri fraksi daun sirih (Piper Betle L) terhadap pertumbuhan bakteri Streptococcus mutans secara in vitro. JMJ. 2016;4(2):140-55.

19. Nalina T, Sarah P, Nick ZHA. The Crude aqueous extract of pipper betle I and its antibacterial effect towards Streptococcus mutans. Am J Biochem \& Biotech. 2003;3(7):105.

20. Hariana $\mathrm{AH}$. Tumbuhan Obat dan Khasiatnya. Jakarta : Penebar Swadaya. 2007.

21. Balagopal SRA. Chlorhexidine: The gold standard antiplaque agent. Journal of Pharmacheutical Sciences and Research. 2013;5(12):270-4.

22. Poureslami HR, Poureslami P, Salari Z, Salari $S$. Comparison of antibacterial effect of fluoride and chlorhexidine on two cariogenic bacteria: an in vitro study. Journal of Dental Biomaterials. 2014;1(1).

23. Susanto M. Potensi minyak atsiri beberapa daun Zingiberaceae sebagai antibakteri Streptococcus mutans dan degradator biofilm pada gigi [skripsi]. Bogor (ID): Fakultas Matematika dan ilmu pengetahuan alam jurusan kimia, Institut Pertanian Bogor. 2015.

24. Ardani M, Pratiwi SUT, Hertiani T. Efek campuran minyak atsiri daun cengkeh dan kulit manis sebagai antiplak gigi. Majalah Farmasi Indonesia. 2010;21(3):191-201.

25. DePaola LG, Spolarich AE. Safety and efficiency of antimicrobial mouthrinses in clinical practice. J of Dent Hyg. 2007;81(5):1-16.

26. Sari SPW, Rahmapuspita F, Iriyani N, Pratiwi SUT, Hertiani T. Penelusuran potensi kapulaga, temu putri dan senggugu sebagai penghambat pembentukan biofilm. Jurnal IImu Kefarmasian Indonesia. 2014;12(1):17-24. 